\title{
Relative Rate Studies of the Reactions of Atomic Chlorine with Acetone and Cyclic Ketones
}

\author{
THUSHANI N. HERATH, IVAN OROZCO, ERIC C. CLINCH, PAUL MARSHALL
}

Department of Chemistry, University of North Texas, Denton, TX, 76203-5070

Received 22 September 2017; revised 20 October 2017; accepted 20 October 2017

DOI 10.1002/kin.21138

Published online 23 November 2017 in Wiley Online Library (wileyonlinelibrary.com).

\begin{abstract}
Rate coefficients have been measured for $\mathrm{Cl}$ atom reactions under ambient conditions with acetone and four cyclic ketones. $\mathrm{Cl}$ was generated by UV photolysis of $\mathrm{Cl}_{2}$, and other species were monitored by FT-IR spectroscopy. The measurements yield $k(\mathrm{Cl}+$ acetone $)=(2.0$ $\pm 0.7) \times 10^{-12}, k(\mathrm{Cl}+$ cyclobutanone $)=(10.1 \pm 0.8) \times 10^{-11}, k(\mathrm{Cl}+$ cycloheptanone $)=(24.0$ $\pm 2.3) \times 10^{-11}, k(\mathrm{Cl}+2$-methyl cyclopentanone $)=(15.2 \pm 1.2) \times 10^{-11}$, and $k(\mathrm{Cl}+2$-methyl cyclohexanone $)=(11.2 \pm 1.0) \times 10^{-11} \mathrm{~cm}^{3}$ molecule ${ }^{-1} \mathrm{~s}^{-1}$, where the uncertainties represent $95 \%$ confidence limits. These results are discussed in the context of structure-activity relationships. We also present a prediction for $\mathrm{Cl}+$ cyclopropanone based on ab initio properties of the transition state. (C) 2017 Wiley Periodicals, Inc. Int J Chem Kinet 50: 41-46, 2018
\end{abstract}

\section{INTRODUCTION}

Carbonyl compounds are important intermediates in the chain of transformations involved in the atmospheric oxidation of organic species [1]. They are also emitted directly into the atmosphere, for example, via their uses as solvents and fuel additives, and from biogenic sources such as plants and biomass burning [2]. The subsequent fate of ketones is typically initiated via attack of hydroxyl radicals or atomic chlorine, or photochemically, and these steps form part of an autocatalytic sequence for oxidation of hydrocarbons [1]. Carbonyl chemistry may lead to the formation of ozone,

Correspondence to: Paul Marshall; e-mail: marshall@unt.edu. Supporting Information is available in the online issue at www.wileyonlinelibrary.com.

(C) 2017 Wiley Periodicals, Inc. organic acids, and/or secondary aerosols [3]. Degradation of volatile organic compounds (VOCs) is typically by photochemistry or by reaction with hydroxyl, but in some parts of the atmosphere such as the Marine Boundary Layer [4] and polar regions [5] the concentration of chlorine atoms is high enough for its chemistry to be competitive.

Here we focus on the initial hydrogen-atom abstraction step by atomic $\mathrm{Cl}$ from the following ketones:

$$
\mathrm{Cl}+\mathrm{CH}_{3} \mathrm{COCH}_{3} \rightarrow \mathrm{HCl}+\mathrm{CH}_{3} \mathrm{COCH}_{2}
$$

$$
\mathrm{Cl}+\text { cyclobutanone } \rightarrow \mathrm{HCl}+\text { products }
$$

$$
\mathrm{Cl}+\text { cycloheptanone } \rightarrow \mathrm{HCl}+\text { products }
$$


Table I Initial Concentration of the Reactants, Integrated Wavenumber Regions, and Rate Coefficient Ratios ( $\left.k_{R} / k_{\text {ref }}\right)$, for the Reactions of Cl Atoms with Ketones at ( $293 \pm 2) \mathrm{K}$

\begin{tabular}{|c|c|c|c|c|c|c|}
\hline Reactant & $\begin{array}{c}{[\text { Reactant }]_{0}} \\
\left(10^{16} \text { molecule } \mathrm{cm}^{-3}\right)\end{array}$ & $\begin{array}{c}\text { Integrated } \\
\text { Range } \\
\left(\mathrm{cm}^{-1}\right)\end{array}$ & Reference & $\begin{array}{c}\text { Integrated } \\
\text { Range } \\
\left(\mathrm{cm}^{-1}\right)\end{array}$ & $\begin{array}{c}{[\text { Reference }]_{0}} \\
\left(10^{16} \text { molecule } \mathrm{cm}^{-3}\right)\end{array}$ & $k_{\mathrm{R}} / k_{\mathrm{ref}} \pm 2 \sigma$ \\
\hline \multirow[t]{2}{*}{ Acetone } & 3.43 & $1700-1800$ & $\begin{array}{c}1,2- \\
\text { Dichloroethane }\end{array}$ & $710-745$ & 2.82 & $1.581 \pm 0.094$ \\
\hline & 4.33 & & Dichloromethane & $730-780$ & 3.45 & $5.512 \pm 0.380$ \\
\hline \multirow[t]{4}{*}{ Cyclobutanone } & 3.24 & $1760-1840$ & Isobutane & $1476-1483$ & 3.51 & $0.697 \pm 0.008$ \\
\hline & 2.72 & & Isobutane & & 2.41 & $0.747 \pm 0.026$ \\
\hline & 3.92 & & Ethene $^{a}$ & $925-975$ & 2.83 & $1.267 \pm 0.030$ \\
\hline & 3.16 & & Ethene $^{b}$ & & 1.95 & $1.166 \pm 0.052$ \\
\hline \multirow[t]{4}{*}{ Cycloheptanone } & 9.24 & & $\begin{array}{c}\text { trans- } \\
\text { Dichloroethene }\end{array}$ & $1185-1220$ & 9.61 & $2.804 \pm 0.246$ \\
\hline & 6.73 & & $\begin{array}{c}\text { trans- } \\
\text { Dichloroethene }\end{array}$ & & 7.00 & $2.260 \pm 0.354$ \\
\hline & 2.50 & & Ethene $^{b}$ & $925-975$ & 5.01 & $2.765 \pm 0.132$ \\
\hline & 1.79 & & Ethene $^{b}$ & & 3.58 & $2.842 \pm 0.086$ \\
\hline \multirow{4}{*}{$\begin{array}{l}\text { 2-Methyl cy- } \\
\text { clopentanone }\end{array}$} & 3.45 & $1700-1800$ & Isobutane & $1476-1483$ & 2.77 & $1.221 \pm 0.036$ \\
\hline & 2.78 & & Isobutane & & 2.23 & $1.096 \pm 0.042$ \\
\hline & 5.19 & & Ethene $^{a}$ & $925-975$ & 8.22 & $1.686 \pm 0.168$ \\
\hline & 5.59 & & Ethene $^{b}$ & & 8.17 & $1.415 \pm 0.180$ \\
\hline \multirow{4}{*}{$\begin{array}{l}\text { 2-Methyl } \\
\text { cyclohexanone }\end{array}$} & 4.33 & & Ethene $^{a}$ & $925-975$ & 5.04 & $1.429 \pm 0.134$ \\
\hline & 4.64 & & Ethene $^{b}$ & & 3.61 & $1.539 \pm 0.092$ \\
\hline & 3.66 & & Isobutane & $1476-1483$ & 2.74 & $0.728 \pm 0.010$ \\
\hline & 2.84 & & Isobutane & & 1.81 & $0.943 \pm 0.142$ \\
\hline
\end{tabular}

${ }^{a}$ With 933 mbar Ar.

${ }^{b}$ With 667 mbar Ar.

$\mathrm{Cl}+2$-methyl cyclopentanone $\rightarrow \mathrm{HCl}+$ products

$\mathrm{Cl}+2$-methyl cyclohexanone $\rightarrow \mathrm{HCl}+$ products

There have been prior studies of such abstraction reactions with cyclic ketones. Wallington et al. [6] and Takahashi et al. [7] measured $\mathrm{Cl}$ plus cyclopentanone and cyclohexanone. The work of Aschmann and Atkinson [8] on Cl plus cycloalkanes and cycloketones included analysis in terms of structure-activity relationships (SAR). These were modified by Farrugia et al. [9], who also highlighted some discrepancies in the prior literature. One goal of this work is to explore the extrapolation of the SAR to new compounds. Because cyclopropanone is unstable at room temperature, we use computational methods to make a prediction for

$$
\mathrm{Cl}+\text { cyclopropanone } \rightarrow \mathrm{HCl}+\text { products }
$$

\section{METHODOLOGY}

Commercial samples were purified by repeated freezepump-thaw cycles with liquid nitrogen. The general principles of relative rate measurements are well established [10], and we have described our apparatus and procedures in detail elsewhere [11]. Briefly, molecular chlorine is photolyzed by steady UV illumination from a mercury pen lamp in the presence of the reactant ketone and a reference compound in a $100-\mathrm{cm}^{3}$ Pyrex multipass IR cell, with a path length of $2.4 \mathrm{~m}$. The Pyrex walls are expected to block lamp emission at 184 and $254 \mathrm{~nm}$ but not at $365 \mathrm{~nm}$. The cell is mounted within a Nicolet iS50 FT-IR spectrometer. The reference compound is a species whose absolute rate constant for reaction with atomic $\mathrm{Cl}$ has been already been characterized at room temperature. The absorbance of the reactant and reference is monitored by infrared (IR) spectroscopy over typically ca. $10 \mathrm{~min}$ with a resolution of $2 \mathrm{~cm}^{-1}$.

With the central assumption that the dominant loss path for both the reactant and the reference is reaction with $\mathrm{Cl}$ atoms, with second-order rate constants of $k_{R}$ 

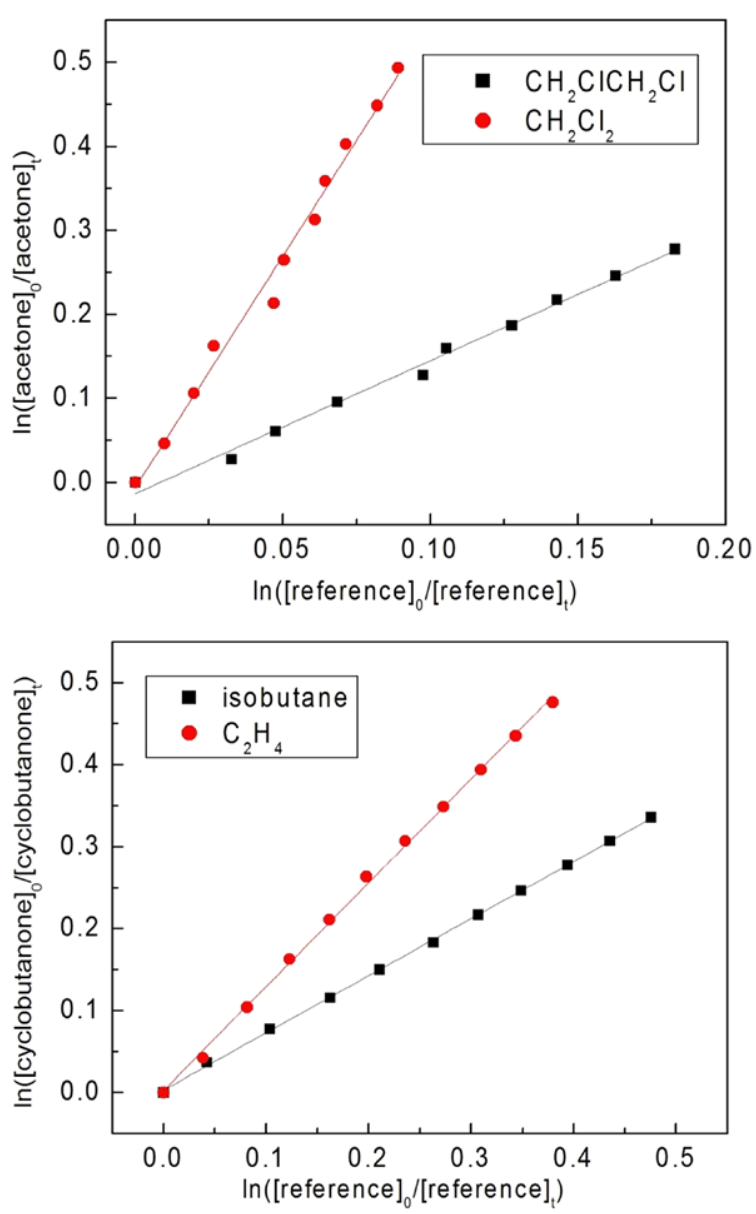

Figure 1 Example plots of concentration of reactant versus reference compound for acetone and cyclobutanone while consumed by atomic $\mathrm{Cl}$. The $(0,0)$ points from different runs overlap. [Color figure can be viewed at wileyonlinelibrary.com]

and $k_{r e f}$, respectively, we may write [10] (where the subscript 0 refers to the initial value and $t$ to a later time)

$$
\ln \left\{\frac{[\text { reactant }]_{0}}{[\text { reactant }]_{t}}\right\}=\frac{k_{\mathrm{R}}}{k_{\text {ref }}} \ln \left\{\frac{[\text { reference }]_{0}}{[\text { reference }]_{t}}\right\}
$$

The ratios of concentration were obtained from ratios of the integrated absorbance over selected regions of the IR spectra, given in Table I, along with the initial conditions. Typically, we employed around 1-3 mbar reference compound, around 1-3 mbar reactant, around 4-12 mbar $\mathrm{Cl}_{2}$, and ca. 900 mbar of Ar. For each reactant, we verified that over a $10-\mathrm{min}$ period photolysis in the absence of $\mathrm{Cl}_{2}$, and storage in the dark with $\mathrm{Cl}_{2}$, did not cause major reaction. Changes in peak area for the ketones under these two conditions were $3-5 \%$ and $3-6 \%$, respectively.

The reference compounds employed were isobutane, trans-1,2-dichloroethene, ethene, 1,2dichloroethane, and dichloromethane. Rate constants and error limits were taken from the most recent measurements, which yielded $k_{\text {ref }}$ values of (1.40 $\pm 0.08) \times 10^{-10} \mathrm{~cm}^{3}$ molecule $\mathrm{s}^{-1} \mathrm{~s}^{-1}$ for isobutane [12], $(9.8 \pm 0.4) \times 10^{-11} \mathrm{~cm}^{3}$ molecule ${ }^{-1} \mathrm{~s}^{-1}$ for trans-1,2-dichloroethene [13], $(1.47 \pm 0.21) \times 10^{-12}$ $\mathrm{cm}^{3}$ molecule $\mathrm{s}^{-1}$ for 1,2-dichloroethane [14], and $(3.5 \pm 0.2) \times 10^{-13} \mathrm{~cm}^{3}$ molecule ${ }^{-1} \mathrm{~s}^{-1}$ for dichloromethane [15]. We used ethene at two pressures, 667 and 933 mbar, and took rate constants at these pressures from the Troe fit to the measurements by Glowacki et al. [16] to obtain 8.6 and $9.9 \times 10^{-11}$ $\mathrm{cm}^{3}$ molecule $\mathrm{s}^{-1} \mathrm{~s}^{-1}$, respectively. Prior data nearly all lie within $15 \%$ of the Troe fit, and so this was taken to be the confidence limit. These results are for $\mathrm{N}_{2}$ or air as the bath gas but our experiments were made with Ar. At the high-pressure limit, the rate constant is of course independent of the nature of the bath gas, but our context is in the falloff region so some dependence is expected. A preliminary analysis of laser-photolysis resonance fluorescence experiments with $\mathrm{Ar}$ and $\mathrm{N}_{2}$ bath gases suggests that in our pressure regime $\mathrm{N}_{2}$ data are a factor of ca. 1.07 higher than Ar results [17]. We therefore divide the $\mathrm{N}_{2}$ results by a factor of 1.07. We combine a $10 \%$ uncertainty arising from this scale factor in quadrature with the $15 \%$ above to propose $k\left(\mathrm{Cl}+\mathrm{C}_{2} \mathrm{H}_{4}\right)=(8.0 \pm 1.4)$ and $(9.3 \pm 1.7) \times$ $10^{-11} \mathrm{~cm}^{3}$ molecule ${ }^{-1} \mathrm{~s}^{-1}$ at room temperature and 667 and 933 mbar Ar, respectively.

\section{RESULTS AND DISCUSSION}

Figure 1 shows example plots of $\ln \left\{[\text { reactant }]_{0} /\right.$ $\left.[\text { reactant }]_{t}\right\}$ versus $\ln \left\{[\text { reference }]_{0} /[\text { reference }]_{t}\right\}$, whose slope is $k_{\mathrm{R}} / k_{\mathrm{ref}}$, for acetone and cyclobutanone reactions with $\mathrm{Cl}$. Further plots are included in the Supporting Information. Table I lists the slopes of plots like those in Fig. 1 together with their $2 \sigma$ statistical uncertainties. Pairs of $k_{\mathrm{R}} / k_{\text {ref }}$ values with each of two references were obtained for the cyclic species. We note that some pairs agree to within the combined $2 \sigma$ but in other cases do not, which reveals that factors other than the statistical uncertainty in slopes of plots like Fig. 1 influence the reproducibility and can cause differences of around $10 \%$. For each reactant, $k_{\mathrm{R}} / k_{\text {ref }}$ is multiplied by the literature value of $k_{\text {ref }}$. We estimate an uncertainty in $k_{R}$ via $2 \sigma$ in the $k_{\mathrm{R}} / k_{\text {ref }}$ ratio combined in quadrature with a $10 \%$ allowance for reproducibility 
Table II Summary of the Rate Constants of Ketones with Cl Atoms Obtained with Different Reference Compounds

\begin{tabular}{|c|c|c|}
\hline Reactant & Reference & $\begin{array}{c}k_{\mathrm{R}} \pm 2 \sigma \\
\left(10^{-11} \mathrm{~cm}^{3} \text { molecule }^{-1} \mathrm{~s}^{-1}\right)\end{array}$ \\
\hline \multirow[t]{2}{*}{ Acetone } & Dichloromethane & $0.232 \pm 0.043$ \\
\hline & 1,2-Dichloroethane & $0.193 \pm 0.026$ \\
\hline \multirow[t]{4}{*}{ Cyclobutanone } & Isobutane & $9.76 \pm 1.13$ \\
\hline & & $10.5 \pm 1.3$ \\
\hline & Ethene & $11.8 \pm 2.5$ \\
\hline & & $9.33 \pm 1.93$ \\
\hline \multirow[t]{4}{*}{ Cycloheptanone } & trans-1,2-Dichloroethene & $27.5 \pm 3.8$ \\
\hline & & $22.1 \pm 4.2$ \\
\hline & Ethene & $22.1 \pm 4.6$ \\
\hline & & $22.7 \pm 4.6$ \\
\hline \multirow[t]{4}{*}{ 2-Methylcyclopentanone } & Isobutane & $17.1 \pm 2.0$ \\
\hline & & $15.3 \pm 1.9$ \\
\hline & Ethene & $15.7 \pm 3.6$ \\
\hline & & $11.3 \pm 2.7$ \\
\hline \multirow[t]{4}{*}{ 2-Methylcyclohexanone } & Ethene & $13.3 \pm 3.0$ \\
\hline & & $12.3 \pm 2.6$ \\
\hline & Isobutane & $10.2 \pm 1.2$ \\
\hline & & $13.2 \pm 2.5$ \\
\hline
\end{tabular}

Table III Comparison of Present Rate Constants for $\mathrm{Cl}$ Atoms Plus Ketones with Literature Data and Values from a Structure-Activity Relation

\begin{tabular}{lccc}
\hline & \multicolumn{3}{c}{$k\left(10^{-11} \mathrm{~cm}^{3}\right.$ molecule $\left.^{-1} \mathrm{~s}^{-1}\right)$} \\
\cline { 2 - 4 } Reactant & This Work & $\mathrm{SAR}^{a}$ & Literature \\
\hline Acetone & $0.20 \pm 0.07$ & - & $0.21 \pm 0.03^{b}$ \\
Cyclobutanone & $10.1 \pm 0.8$ & 6.1 & - \\
Cycloheptanone & $24.0 \pm 2.3$ & 22.6 & $24.6 \pm 0.7^{c}$ \\
2-Methylcyclopentanone & $15.2 \pm 1.2$ & 12.2 & - \\
2-Methylcyclohexanone & $11.2 \pm 1.0$ & 17.7 & - \\
\hline
\end{tabular}

${ }^{a}$ Parameterization from 9 .

${ }^{b}$ From 19.

${ }^{c}$ From 8.

and with the literature uncertainty for the reference compound. These results are summarized in Table II. The weighted mean of $k_{\mathrm{R}}$ was evaluated as outlined by Bevington [18] to yield the final results in Table III. The $1 \sigma$ uncertainty of the weighted mean multiplied by Student's $t$ value of 3.18 (based on 3 degrees of freedom) was combined in quadrature with a $3 \%$ estimate of possible systematic errors in pressure and concentration measurements to obtain $95 \%$ confidence limits.

It may be seen that where comparison is possible our measurements agree with the literature, that is, for reactions of atomic $\mathrm{Cl}$ with acetone [19] and cycloheptanone [8]. Figure 2 shows a comparison between

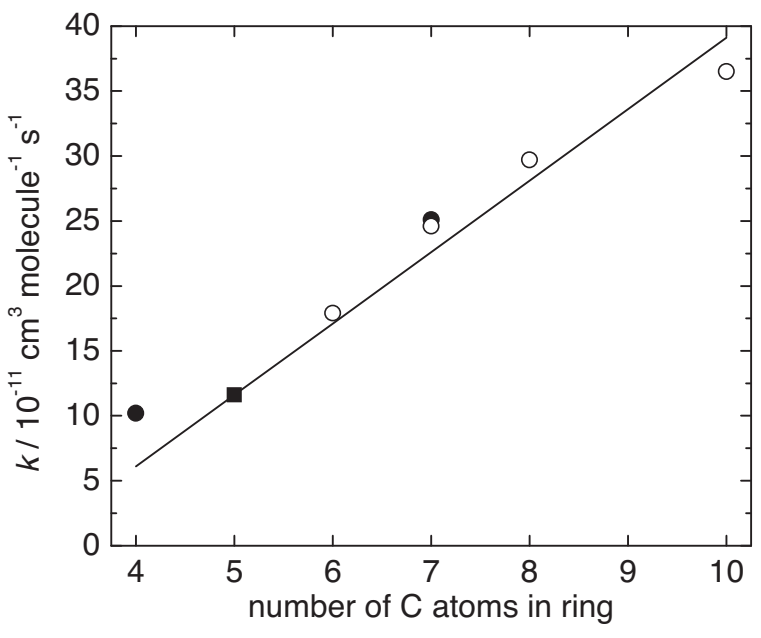

Figure 2 Comparison of measured rate constants for $\mathrm{Cl}$ + cycloketones with values obtained from SAR parameterization. Solid circles, present work; solid square, Takahashi et al. [7]; open circles, [8]; solid line, SAR from Farrugia et al. [9].

measured rate constants for $\mathrm{Cl}$ plus cycloketones and SAR values by Farrugia et al. [9] as a function of ring size. The overall agreement is good, although our data for cyclobutanone lie a factor of 1.7 above the prediction. This could reflect ring strain. To explore this idea further, we considered cyclopropanone. Experimental study of reaction (6) at room temperature is not feasible so we have computed the structures, 


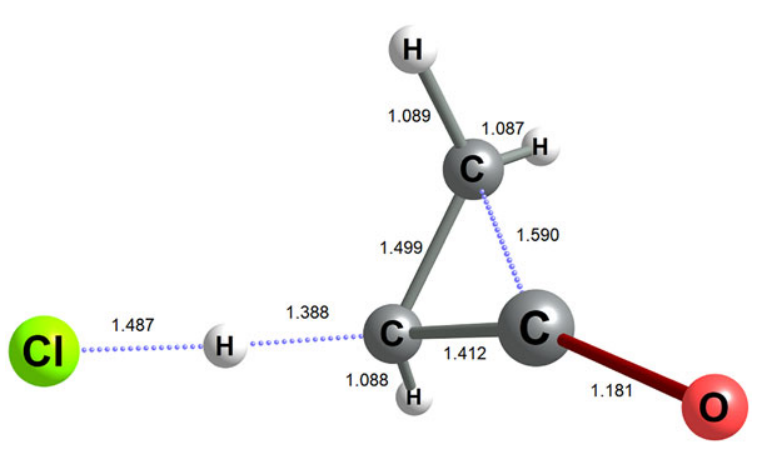

Figure 3 Structure of transition state for $\mathrm{Cl}+$ cyclopropanone computed with B3LYP/6-31G(2df,p) theory. Bond lengths are shown in $10^{-10} \mathrm{~m}$ (see the Appendix for complete geometry). [Color figure can be viewed at wileyonlinelibrary.com]

vibrational frequencies, and energies of the reactants and transition state (TS) using the G4 method [20], implemented in the Gaussian 16 program [21]. The structure of the TS is shown in Fig. 3, and ab initio data are given in the Appendix; the key result is that the energy of the TS including zero-point vibrational energy is within $0.5 \mathrm{~kJ} \mathrm{~mol}^{-1}$ of the reactants so that the predicted activation energy is effectively zero. Given a preexponential factor for $\mathrm{Cl}+$ cyclopropane of $1.8 \times$ $10^{-10} \mathrm{~cm}^{3}$ molecule s ${ }^{-1}$ [22], we expect that $k_{6}$ for cyclopropanone, which has only two methylene groups rather than three, is about $1.2 \times 10^{-10} \mathrm{~cm}^{3}$ molecule $\mathrm{s}^{-1}$. This is marginally larger than $k_{2}$, about a factor of 20 greater than an SAR extrapolation, and about a factor of 60 greater than $k_{1}$. The $\mathrm{C}-\mathrm{H}$ bonds adjacent to the carbonyl group in cyclopropanone are clearly much more reactive than the $\mathrm{C}-\mathrm{H}$ bonds next to the carbonyl group in acetone. Following the reaction coordinate reveals an interesting feature of reaction (6). Abstraction from $\mathrm{C}-\mathrm{H}$ is concerted with ring opening, so that the initial products of reaction (6) are $\mathrm{HCl}+$ 3-oxo 2-propenyl and not oxo-cyclopropyl radicals.

While there is reasonable performance of the SAR for the two methylcycloketones listed in Table III, with agreement with experiment to within a factor of 1.6, we note that the order of reactivity is reversed compared to the predictions. Possibly some further parameterizations are needed to reproduce the experimentally observed behavior.

Finally, we comment that for the cyclic compounds here the rate constants with $\mathrm{Cl}$ are on the order of 40 times larger than those for the reactions with $\mathrm{OH}$ radicals. This means that in atmospheric regions with high $[\mathrm{Cl}]$, such as the Marine Boundary Layer where $[\mathrm{Cl}] \sim(1 / 4)[\mathrm{OH}]$, we can expect $\mathrm{Cl}$ atom chemistry to dominate for these species.

\section{CONCLUSIONS}

Relative rate results for $\mathrm{Cl}+$ cycloketones show good agreement with a prior structure-activity relation, but results for small rings, especially ab initio analysis of cyclopropanone, show deviations which we attribute to the influence of ring strain. Results for two methylsubstituted cycloketones indicate some deviation from the SAR.

Assistance in the laboratory was provided by Erin Raign and Kejun Shao. This work was supported by the Robert A. Welch Foundation (Grant B-1174). Computer facilities were purchased with NSF grant CHE-1531468.

\section{APPENDIX: COMPUTATIONAL ANALYSIS OF CL + CYCLOPROPANONE WITH G4 THEORY}

\begin{tabular}{lrrr}
\multicolumn{4}{c}{ Cyclopropanone geometry (in $10^{-10} \mathrm{~m}$ ) } \\
\hline $\mathrm{C}$ & -0.000000000 & 0.785525000 & -0.858941000 \\
$\mathrm{C}$ & -0.000000000 & -0.785525000 & -0.858941000 \\
$\mathrm{C}$ & 0.000000000 & -0.000000000 & 0.385640000 \\
$\mathrm{O}$ & 0.000000000 & -0.000000000 & 1.580526000 \\
$\mathrm{H}$ & -0.913453000 & -1.289154000 & -1.162689000 \\
$\mathrm{H}$ & 0.913453000 & -1.289154000 & -1.162689000 \\
$\mathrm{H}$ & -0.913453000 & 1.289154000 & -1.162689000 \\
$\mathrm{H}$ & 0.913453000 & 1.289154000 & -1.162689000
\end{tabular}

Unscaled vibrational frequencies (in $\mathrm{cm}^{-1}$ )

$327,512,629,701,730,947,1022,1057,1067,1107,1166$, $1417,1431,1957,3117,3118,3197,3211$

TS geometry (in $10^{-10} \mathrm{~m}$ )

\begin{tabular}{lrrr}
\hline $\mathrm{C}$ & -0.409479000 & 0.435306000 & 0.630434000 \\
$\mathrm{C}$ & -1.209868000 & 1.250668000 & -0.339451000 \\
$\mathrm{C}$ & -1.506232000 & -0.256531000 & 0.072169000 \\
$\mathrm{O}$ & -2.238806000 & -1.158524000 & -0.140921000 \\
$\mathrm{H}$ & -1.809734000 & 2.096240000 & -0.013790000 \\
$\mathrm{H}$ & -0.903482000 & 1.261055000 & -1.384617000 \\
$\mathrm{H}$ & -0.392366000 & 0.688058000 & 1.688491000 \\
$\mathrm{H}$ & 0.854942000 & 0.027578000 & 0.229606000 \\
$\mathrm{Cl}$ & 2.289092000 & -0.198906000 & -0.092426000 \\
\hline
\end{tabular}

Unscaled vibrational frequencies (in $\mathrm{cm}^{-1}$ )

847i, 80, 109, 337, 372, 478, 493, 769, 803, 864, 934, 977,

1020, 1066, 1166, 1186, 1449, 1974, 3101, 3159, 3201 
G4 energies at $0 \mathrm{~K}$ (including zero-point energy, in Hartrees)

\begin{tabular}{ll}
\hline $\mathrm{Cl}$ & -460.013636 \\
Cyclopropanone & -191.773945 \\
$\mathrm{TS}$ & -651.787772 \\
\hline
\end{tabular}

\section{BIBLIOGRAPHY}

1. Lary, D. J.; S, D. E., J Geophys Res 2000, 105, 1977119778.

2. Kesselmeier, J.; Staudt, M. J Atmos Chem 1999, 33, 23-88.

3. Kroll, J. H.; Ng, N. L.; Murphy, S. M.; Varutbangkul, V.; Flagan, R. C.; Seinfeld, J. H. J Geophys Res 2005, 110, D23207.

4. Spicer, C. W.; Chapman, E. G.; Finlayson-Pitts, B. J.; Plastridge, R. A.; Hubbe, J. M.; Fast, J. D.; Berkowitz, C. M. Nature 1998, 394, 353-356.

5. Liao, J.; Huey, L. G.; Liu, Z.; Tanner, D. J.; Cantrell, C. A.; Orlando, J. J.; Flocke, F. M.; Shepson, P. B.; Weinheimer, A. J.; Hall, S. R.; Ullmann, K.; Beine, H. J.; Wang, Y.; Ingall, E. D.; Stephens, C. R.; Hornbrook, R. S.; Ape, E. C.; Riemer, D.; Fried, A.; R.L. Mauldin, I.; Smith, J. N.; Staebler, R. M.; Neuman, J. A.; Nowak, J. B. Nature Geosci 2014, 7, 91-94.

6. Wallington, T. J.; Guschin, A.; Hurley, M. D. Int J Chem Kinet 1998, 30, 309-310.

7. Takahashi, K.; Iwasaki, E.; Matsumi, Y.; Wallington, T. J. J Phys Chem A 2007, 111, 1271-1276.

8. Aschman, S. M.; Atkinson, R. Int J Chem Kinet 2013, $45,52-58$.

9. Farrugia, L. N.; Bejan, I.; Smith, S. C.; Medeiros, D. J.; Seakins, P. W. Chem Phys Lett 2015, 640, 8793.

10. Atkinson, R. Chem Rev 1985, 85, 69-201.

11. Herath, T. N.; Clinch, E. C.; Orozco, I.; Raign, E. L.; Marshall, P. J Phys Chem A 2016, 120, 73117319.

12. Beichert, P.; Wingen, L.; Lee, J.; Vogt, R.; Ezell, M. J.; Ragains, M.; Neavyn, R.; Finlayson-Pitts, B. J. J Phys Chem 1995, 99, 13156-13162.
13. Morozov, I. I.; Nielsen, C.; Morozova, O. S.; Vasiliev, E. S.; Loukhovitskaya, E. E. Russ Chem Bull 2010, 59, 754-760.

14. Sarzynski, D. S.; Fojcik, L.; Gola, A. A.; Berkowski, R.; Jodkowski, J. T.; Latajka, Z. Chem Phys Lett 2014, 597, 86-93.

15. Sarzynski, D.; Gola, A. A.; Brudnik, K.; Jodkowski, J. T. Chem Phys Lett 2011, 514, 220-225.

16. Glowacki, D. R.; Goddard, A.; Hemavibool, K.; Malkin, T. L.; Commane, R.; Anderson, F.; Bloss, W. J.; Heard, D. E.; Ingham, T.; Pilling, M. J.; Seakins, P. W. Atmos Chem Phys 2007, 7, 5371-5390.

17. Alecu, I. M.; Kerr, K. E.; Thompson, K.; Wallace, N.; Gao, Y.; Marshall, P. In 237th American Chemical Society Meeting Salt Lake City; UT, 2009.

18. Bevington, P. R. Data Reduction and Error Analysis for the Physical Sciences; McGraw-Hill: New York, 1969, p. 88.

19. Atkinson, R.; Baulch, D. L.; Cox, R. A.; Crowley, J. N.; Hampson, R. F.; Hynes, R. G.; Jenkin, M. E.; Rossi, M. J.; Troe, J. Atmos Chem Phys 2006, 6, 3625-4055.

20. Curtiss, L. A.; Redfern, P. C.; Raghavachari, K. J Chem Phys 2007, 126, 084108.

21. Frisch, M. J.; Trucks, G. W.; Schlegel, H. B.; Scuseria, G. E.; Robb, M. A.; Cheeseman, J. R.; Scalmani, G.; Barone, V.; Petersson, G. A.; Nakatsuji, H.; Li, X.; Caricato, M.; Marenich, A. V.; Bloino, J.; Blanesko, B. G.; Gomperts, R.; Mennucci, B.; Hratchian, H. P.; Ortiz, J. V.; Izmaylov, A. F.; Sonnenberg, J. L.; Williams-Young, D.; Ding, F.; Lipparini, F.; Egidi, F.; Goings, J.; Peng, B.; Petrone, A.; Henderson, T.; Ranasinghe, D.; Zakrzewski, V. G.; Gao, J.; Rega, N.; Zheng, G.; Liang, W.; Hada, M.; Ehara, M.; Toyota, K.; Fukuda, R.; Hasegawa, J.; Ishida, M.; Nakajima, T.; Honda, Y.; Kitao, O.; Nakai, H.; Vreven, T.; Throssell, K.; J.A. Montgomery, J.; Peralta, J. E.; Ogliaro, F.; Bearpark, M. J.; Heyd, J. J.; Brothers, E. N.; Kudin, K. N.; Staroverov, V. N.; Keith, T. A.; Kobayashi, R.; Normand, J.; Raghavachari, K.; Rendell, A. P.; Burant, J. C.; Iyengar, S. S.; Tomasi, J.; Cossi, M.; Millam, J. M.; Klene, M.; Adamo, C.; Cammi, R.; Ochterski, J. W.; Martin, R. L.; Morokuma, K.; Farkas, O.; Foresman, J. B.; Fox, D. J. Gaussian 16 (rev. A.03); Gaussian: Wallingford, CT, 2016.

22. Hurley, M. D.; Schneider, W. F.; Wallington, T. J.; Mann, D. J.; DeSain, J. D.; Taatjes, C. A. J Phys Chem A 2003, 107, 2003-2010. 